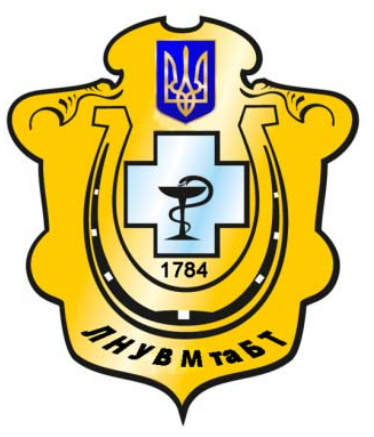

Науковий вісник Львівського національного університету ветеринарної медицини та біотехнологій імені С.3. Гжицького

Scientific Messenger of Lviv National University of Veterinary Medicine and Biotechnologies named after S.Z. Gzhytskyj

doi:10.15421/nvlvet7041

ISSN 2413-5550 print

ISSN 2518-1327 online

$\underline{\text { http://nvlvet.com.ua/ }}$

УДК 636.2: 619:616.1/.44 (477.42)

\title{
Поширення, етіологія та діагностика гіпотиреозу у корів Житомирського Полісся
}

\author{
І.П. Лігоміна, С.В. Фурман, Д.В. Лісогурська \\ ligomina@mail.ru; svitlana.furman@yandex.ua; lisogurska@mail.ru \\ Житомирський національний агроекологічний університет, \\ Старий бульвар, 7, м. Житомир, 10002, Украӥна
}

\begin{abstract}
Житомирське Полісся Украӥни є частиною біогеохімічної зони, яка характеризується недостатнім умістом біотичних мікроелементів, у тому числі Йоду, дефічит якого в довкіллі є загальною біологічною й медичною проблемою. Тварини, перебуваючи в єдиному трофічному ланцюгу з людиною, більшою мірою відчувають геохімічні та екологічні впливи. Основною причиною зниження функиіональної активності щитоподібної залози у корів є низький уміст Йоду у трунтах $і$ як наслідок у кормах та забруднення їх радіонуклідами $-{ }^{137} \mathrm{Cs} i{ }^{90} \mathrm{Sr}$. Сприяють розвитку даної патології низький валовий вміст у трунтах даної території синергістів Йоду - Кобальту - 1,7 -2,5 мг/кг (оптимальний 7 - 30), Міді -1,1 - 2,7 (15 - 60), Цинку - 13,2 - 31,0 мг/кг (30 - 70), а в деяких місиях і Марганию.

Клінічними дослідженнями були встановлені симптоми йодної недостатності, типові для гіпотиреозу: сухість і гіперкератоз шкіри, довге волосся в ділянці холки, анемічність кон'юнктиви, енофтальм, брадикардія, мікседема, збільшення щитоподібної залози. У 90\% корів виявлена гіпофункиія щиитоподібної залози: уміст тироксину в сироватці крові був у межах від 28,3 до 54,7 нмоль/л і в середньому становив 43,8 $\pm 2,7$ нмоль/л $(3,4 \pm 0,21$ мкг/100 мл).

За дефіциту мікроелементів порушується гемопоез з розвитоком анемії у $85 \%$ корів, щзо виражається олігоцитемією (y $75-80 \%)$ і олігохромемією $(41,7-66,7 \%)$. Анемія у корів, в основному, макроцитарна і гіпехромна, рідше - нормохромна. Еритрограма корів відзначається більш тривалою, порівняно з тваринами умовно чистої території, лівою частиною, ще вказує на значну кількість «старих» за віком еритроцитів, і розтягнутою правою частиною, що зумовлено підвищеною кількістю більш стійких до гемолізу незрілих «молодих» еритроцитів.

Ключові слова: мікроелементи, Йод, радіонукліди, корови, гіпотиреоз, гемопоез, анемія, еритрограма, брадикардія, мікседема, тироксин.
\end{abstract}

\section{Распространение, этиология и диагностика гипотиреоза у коров Житомир- ского Полесья}

\author{
И.П. Лигомина, С.В. Фурман, Д.В. Лисогурская \\ ligomina@mail.ru; svitlana.furman@yandex.ua; lisogurska@mail.ru \\ Житомирский национальный агроэкологический университет, \\ Старый бульвар, 7, г. Житомир, 10002, Украина
}

\begin{abstract}
Житомирское Полесье Украины есть частью биогеохимической зоны, которая характеризуется недостаточным содержанием биотических микроэлементов, в том числе Йода, дефіиит которого в окружающей среде есть общей биологической и медииисккой проблемой. Животные, находясь в едином трофическом звене с человеком, в большей степени чувствуют геохимическое и экологическое влияние. Основной причиной уменьшения функииональной активности щзитовидной железы у коров есть низкое содержание Йода в почве и как следствие в кормах и загрязнение их радионуклидами - ${ }^{137} \mathrm{Cs} u$ ${ }^{90} \mathrm{Sr}$. Сопутствуют развитию данной патологии сниженное валовое содержание в почвах данной территории синергистов Йода- кобальта - 1,7 -2,5 мг/кг (оптимальное 7 - 30), Меди - 1,1 - 2,7 (15-60), Цинка - 13,2 - 31,0 мг/кг (30 - 70), а в некоторых местах и Марганияа.
\end{abstract}

\section{Citation:}

Ligomina, I.P., Furman, S.V., Lysogurska, D.V. (2016). Distribution, etiology and diagnosis of hypothyroidism in cows of the Zhytomyr Polissya. Scientific Messenger LNUVMBT named after S.Z. Gzhytskyj, 18, 3(70), 174-177. 
Клиническими исследованиями были установлены симптомы йодной недостаточности, типичные для гипотиреоза: сухость и гиперкератоз кожи, длинные волосы в области холки, анемичность конъюнктивь, энофтальм, брадикардия, микседема, увеличение щичтовидной железы. Так, у 90\% коров выявлена гипофункция шуитовидной железы: содержание тироксина в сыворотке крови колеблется от 28,3 до 54,7 нмоль/л и в среднем составляло 43,8 $\pm 2,7$ нмоль/л (3,4 \pm 0,21 мкг/100 мл).

Дефицит микроэлементов вызывает нарушение гемопоэза и развитие анемии у 85\% коров, что выражается олигоцитемией (у 75 - 80\%) и олигохромемией (41,7 - 66,7\%). Анемия у коров, в основном, развивается макроцитарная и гиперхромная, реже - нормохромная.

Эритрограмма коров отличается более длительной, в сравнении с животньми из благополучной зонь, левой частью, что указывает на значительное количество «старых» по возрасту эритроцитов, и растянутой правой частью, что обусловлено повышенным количеством более стойких к гемолизу «молодых» эритроцитов.

Ключевые слова: микроэлементы, Йод, радионуклиды, коровы, гипотиреоз, гемопоэз, анемия, эритрограмма, брадикардия, микседема, тироксин.

\title{
Distribution, etiology and diagnosis of hypothyroidism in cows of the Zhytomyr Polissya
}

\author{
I.P. Ligomina, S.V. Furman, D.V. Lysogurska \\ ligomina@mail.ru; svitlana.furman@yandex.ua; lisogurska@mail.ru \\ Zhytomyr national agroecological university, \\ Staryj Boulevard, 7, Zhytomyr, 10002, Ukraine
}

\begin{abstract}
Zhytomyr Polissya of Ukraine is part of the biogeochemical zones, which is characterized by insufficient content of biotic trace elements, including iodine, lack of which in the environment is a common biological and medical problem. Animals, which being in a single food chain with a man, have geochemical and environmental impacts in a greater degree. The main reason for the decrease in the functional activity of the thyroid gland in cows is low iodine content in soils and, as a consequence, in animal feed and their contamination with radionuclides $-{ }^{137} \mathrm{Cs}$ and ${ }^{90} \mathrm{Sr}$. Low total contents in the soil of the territory of the synergists of iodine - cobalt$1.7-2.5 \mathrm{mg} / \mathrm{kg}$ (optimal 7 -30), copper -1.1 - 2.7 (15 - 60), zinc - 13.2-31.0 mg/kg (30-70), and in some places, and manganese contribute to the development of this disease.

The symptoms of iodine deficiency, which is typical for hypothyroidism: dryness and hyperkeratosis of the skin, the long hair site the withers, anemone conjunctiva, enophthalm, bradycardia, myxedema, thyroid enlargement were installed by clinical studies. So, $90 \%$ of the cows revealed hypofunction of the thyroid gland: content thyroxine the blood serum was in the range 28.3 to $54.7 \mathrm{nmol} / \mathrm{l}$ and averaged a $43.8 \pm 2.7 \mathrm{nmol} / \mathrm{l}(3.4 \pm 0.21 \mathrm{mg} / 100 \mathrm{ml})$.

Micronutrient deficiency causes a disruption of haematopoiesis and the development of anemia in $85 \%$ of cows that expressed agociting (75 - 80\%) and olgahoney (of 41.7 - 66.7 percent). Anemia, mainly macrocytic and hyperchromic, rarely normochromic.

Erythrogramma of cows notes longer left part, compared with animals a safe zone, that indicates on a significant number of «old» age of red blood cells, and stretched the right part that is due to the increased number of more resistant to hemolysis immature «young» erythrocytes.
\end{abstract}

Key words: trace elements, iodine, radionuclides, cows, hypothyroidism, hematopoiesis, anemia, erythrogram, bradycardia, myxedema, thyroxine.

\section{Вступ}

Радіоактивне забруднення довкілля досягло глобальних катастрофічних масштабів. Для довкілля найтяжчими стали наслідки найбільшої техногенної катастрофи, що сталася на ЧАЕС у 1986 р. (Slavov et al., 1988).

Унаслідок Чорнобильської катастрофи в Україні забруднено ${ }^{137} \mathrm{Cs}$ та ${ }^{90} \mathrm{Sr}$ близько 4,6 млн/га сільськогосподарських угідь. Пошкоджень зазнали агроекосистеми у межах 74 районів 11 областей, особливо Київської, Житомирської, Рівненської і Волинської (Romanchuk, 1996). Особливо небезпечним є хронічне внутрішне опромінення, яке зумовлене радіонуклідами 3 тривалим періодом напіврозпаду (Ligomina et al., $2008,2013)$. Останнім часом серед захворювань великої рогатої худоби особливе місце посідають ендемічні хвороби (Sudakov et al., 1991). Це пов'язане з нестачею в грунті та кормах мікроелементів, післячорнобильським забрудненням території, проведенням певних агрохімічних й агротехнічних заходів, спрямованих на ліквідацію наслідків чорнобильської ава- рії та вивченням впливу на організм людини і тварин (Romanchuk, 1996; Romanjuk et al., 1998; Ligomina et al., 2008, 2013).

У працях М.О.Судакова зі співавт. (Sudakov et al., 2000) найчастіше зустрічається термін «йодна недостатність». На думку Левченко В., Романюк В., В. Фасолі (Levchenko et al., 2001), синдром йодної недостатності проявляється здебільшого гіпофункцією щитовидної залози (гіпотиреоз, зоб).

Саме тому метою роботи було дослідити поширення, етіологію та діагностику гіпотиреозу у корів Житомирського Полісся.

\section{Матеріал і методи досліджень}

Було проведене клінічне дослідження дійних корів у Народицькому, Коростенському та Попільнянському (умовно чиста територія) районах Житомирської області. Кров досліджували від 90 корів (відповідно 59, 16 і 15 голів). Згідно картосхеми Житомирської області, на якій відмічено рівень радіоактивного забруднення населених пунктів за ${ }^{137} \mathrm{Cs} \mathrm{i}{ }^{90} \mathrm{Sr}$, Народи- 
цький район відносився до території зі щільністю забруднення сільськогосподарських угідь за ${ }^{137} \mathrm{Cs}$ 185-370 кБк/м² (підвищений рівень). Забрудненість угідь Коростенського району становила 37 185 кБк/м ${ }^{2}$ за ${ }^{137} \mathrm{Cs}$. Тварини 3 Попільнянського району, де проводились контрольні дослідження, відносяться до території з природним фоном (від 0 до

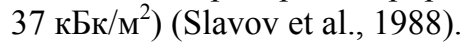

Функціональний стан щитоподібної залози вивчали за вмістом тироксину, який визначали методом IФA 3 використанням тест-системи Triniti Biotech Cahtia $\mathrm{T}_{4}$. Вміст гемоглобіну визначали гемоглобінціанідним методом, загальну кількість еритроцитів меланжерним методом. На основі цих даних розраховували вміст гемоглобіну в одному еритроциті (ВГЕ). Кислотну резистентність еритроцитів 3 наступною побудовою еритрограм вивчали за I.I. Гітельзоном та І.А. Терськовим у модифікації В.П. Москаленко.

\section{Результати та їх обговорення}

При зовнішньому огляді тварин виявляли набряк у міжщелеповому просторі - мікседему, яка встановлена лише у 5-ти з 90 дійних корів $(5,6 \%)$, здебільшого 3 Народицького району (8,9\%), порівняно з 2,2\% - у Коростенському районі. Мікседема $є$ типовим проявом йодної недостатності (Romanchuk, 1996). Розвиток іï пояснюється накопиченням у всіх шарах шкіри кислих глікозамінгліканів (переважно гіалуронової кислоти і менше - хондроїтинсульфатів), надлишок яких змінює колоїдну структуру сполучної тканини, посилює їі гідрофільність і зв'язує Натрій (Sudakov et al., 1991; Romanjuk et al., 1998; Sudakov et al., 2000; Levchenko et al., 2001).

Типовою ознакою йодної недостатності $є$ збільшення розмірів щитоподібної залози. Зоб був встановлений лише у 3 корів з 90 (3,35\%), всі вони були в Народицького району (6,7\%). Збільшення було двобічним, консистенція залози щільна. Енофтальм виявлений у 24 дійних корів з 90 (26,7\%), у т.ч. в 16 з 45 корів $(35,4 \%)$ Народицького району, а у дійних корів Попільнянського району цей симптом не виявляли.

При дослідженні серцево-судинної системи виявляли брадикардію та тенденцію до іiі розвитку у 52 корів 390 (57,8\%). 3 інших симптомів, як правило, в зоні біогеохімічної провінції та радіоактивного забруднення виявили типові ознаки мікроелементної недостатності: сухість і зниження еластичності шкіри, алопеції в різних ділянках шиї та попереку, ріст довгого грубого волосся на голові між рогами (чілка) і на холці (грива), волосяний покрив тьмяний, скуйовджений. Такі зміни відмічені нами у $80 \%$ дійних корів 3 господарств Народицького і Коростенського районів та лише в третини корів Попільнянського району. Зміни волосяного покриву характерні для полімікроелеметної (Йоду, Кобальту, Міді) недостатності. Окрім того, у 37,7\% дійних корів Народицького району виявили депігментацію волосяного покриву навколо очей («окуляри») - симптом, який є типовим для нестачі Міді. Дещо менше $(27,7 \%)$ таких корів було в господарстві Коростенського району. Пояснюється депігментація порушенням синтезу ферменту тирози- нази, яка каталізує біосинтез меланіну (Levchenko et al., 2001).

При дослідженні видимих слизових оболонок найбільшу увагу звертали на колір кон'юнктиви. У $84,4 \%$ корів Коростенського і 95,5\% Народицького районів установлено анемічність кон'юнктиви: колір ііі був від блідо-рожевого до блідого і навіть 3 фарфоровим відтінком.

Кількість еритроцитів у корів з території радіоактивного забруднення становила відповідно 4,6 \pm 0,15 $(\mathrm{p}<0,001)$ i 4,7 $\pm 0,14(\mathrm{p}<0,001)$ Т/л, порівняно 3 $6,4 \pm 0,17$ T/л у корів контрольної групи. Олігоцитемія встановлена у 75\% корів Коростенського і $80 \%$ - Народицького районів. Середній уміст гемоглобіну у корів Народицького району становив 94,8 $\pm 2,3$ $(\mathrm{p}<0,001)$, і Коростенському - 98,7 \pm 3,0 г/л ( $<<0,001)$, порівняно з 113,3 $\pm 1,8-$ у Попільнянському, серед дійних цей показник був знижений у 41,7\% корів з обох зон. Для більш детального аналізу характеру цих змін нами розрахований вміст гемоглобіну в одному еритроциті (ВГЕ). Дослідження ВГЕ показали розвиток гіперхромії у 62,5\% корів Коростенського і $60 \%$ Народицького районів. У решти корів еритроцити були нормохромними.

При анемії має місце зменшення в одиниці об'єму крові гемоглобіну або еритроцитів чи обох показників паралельно. Аналіз показує, що анемія виявлена у 17 корів з 20 (85\%) у Народицького району, причому у $64,7 \%$ корів анемія гіперхромна, у 35,3\% - нормохромна. У 9 корів з 17 (52,9\%) має місце як олігоцитемія, так і олігохромемія. Анемія у 66,7\% 3 них - гіперхромна, у решти - нормохромна. За одержаними даними, видно, що у корів Народицького району, частка «молодих» еритроцитів коливається в межах від 42,5\% до 53,2\% і становить в середньому 48,5 $\pm 1,2 \%$, а частка старих вірогідно ( $<<0,05)$ більша, порівняно 3 коровами 3 інших районів $(14,8 \pm 0,94 \%)$.

Кислотний гемоліз еритроцитів крові корів, що знаходяться в зоні полімікроелементної недостатності та малоінтенсивного радіаційного випромінювання, різнився більш тривалим руйнуванням клітин, нижчим та зміщеним вправо основним піком, порівняно 3 еритроцитами крові корів з чистої зони, які утримувалися на збалансованому раціоні. Вихід основного піка дослідних корів починався 3 4-ї хвилини, що на 0,5 хв. пізніше, а висота його була на 10,8\% меншою, ніж у корів контрольної групи (17,2\% проти 28,0\%). Максимального гемолізу еритроцити дослідних корів зазнавали на 5,5 хв., тоді як у контрольних - на 4,5 хв. Повне руйнування еритроцитів відмічали відповідно на 9 та 7 хвилинах. Отже, крива кислотної резистентності (еритрограма) характеризується більш тривалою лівою частиною, що є показником більшої кількості «старих» еритроцитів у крові, розтягнутою (більш тривалою) правою частиною, що характеризує підвищену кількість більш стійких для гемолізу «молодих» еритроцитів.

Аналіз показує, що вміст Міді та Кобальту в 1 кг сухої речовини раціону дійних тварин низький: у Коростенському районі він становить 3,1 та 0,15 мг, у 
Народицькому - 4,1та 0,19 мг (за нормами 5 - 10 i $0,3-0,8$ мг).

Таким чином, важливим чинником у розвитку зоба $\epsilon$ дефіцит Йоду у грунтах і грунтових водах. За цим показником північні райони Житомирщини належать до регіонів, де ймовірність виникнення зобної ендемії середня, а подекуди - й велика. У грунтах даної території низький валовий вміст синергістів Йоду: Кобальту - 1,7 - 2,5 мг/кг (оптимальний $7-30)$, Міді - 1,1 - 2,7 (15 - 60), Цинку - 13,2 - 31,0 мг/кг $(30-70)$. Згідно з системою біогеохімічного районування зони йодної і кобальтової недостатності збігаються.

Для підтвердження цього діагнозу нами проведено визначення кількості $\mathrm{T}_{4}$ (тироксину) в сироватці крові 10-ти корів з Народицького району та 6-ти корів 3 Коростенського району. Встановлено, що уміст тироксину у дійних корів був у межах відповідно від 2,2 до 4,25 мкг/100 мл (28,3 - 54,7 нмоль/л) і становив в середньому 3,4 \pm 0,21 мкг/100 мл (43,8 $\pm 2,70$ нмоль/л, у корів з Попельнянського району (умовно чиста територія) $-5,3 \pm 0,65$ нмоль/л.

Якщо у корів 3 Попільнянського району уміст $\mathrm{T}_{4}$ був більший 4 мкг/100 мл (> 51,6 нмоль/л), то у корів Народицького району лише в однієї корови (10\%) тироксину було більше цієї кількості, а корів зі вмістом тироксину меншим 50 нмоль/л було 9 (90\%). Отже, у корів дослідного господарства встановлена гіпофункція щитоподібної залози.

Окрім визначення функціонального стану щитоподібної залози, нами визначався рівень Міді, Заліза і Цинку в сироватці крові. Вміст Міді в сироватці крові корів Коростенського району коливався в межах від 12,4 до 14,9 мкмоль/л і був менший мінімальної норми (14,2 мкмоль/л) у 9 з 15 корів (60\%), в середньому Міді було 13,8 \pm 0,18 мкмоль/л. У корів Народицького району середній уміст становив 13,1 \pm 0,20 мкмоль/л і був менший на 6,5 і 11,8\%, порівняно $з$ тваринами Коростенського і Попільнянського району $(\mathrm{p}<0,01)$.

\section{Висновки}

Негативний вплив абіотичних факторів на корів у зоні Полісся Житомирщини - дефіцит есенціальних мікроелементів (J, Co, $\mathrm{Cu}, \mathrm{Zn})$, вплив іонізуючого випромінювання - спричинює розвиток у тварин полімікроелементної недостатності, яка супроводжується зниженням функціонального стану щитоподібної залози - гіпотиреозом. Патологію щитоподібної залози посилює дефіцит в раціоні синергістів йоду - Кобальту, Міді та Цинку. Дефіцит мікроелементів спричинює порушення гемопоезу і розвиток анемії у 85\% корів, що виражається олігоцитемією і олігохромемією. Анемія, в основному, макроцитарна і гіпехромна, рідше - нормохромна. Порушення мінерального обміну у корів характеризується зниженням умісту у сироватці крові Міді, Кобальту і Цинку. У 90\% корів виявлена гіпофункція щитоподібної залози: уміст тироксину був у межах від 28,3 до 54,7 нмоль/л і в середньому становив 43,8 $\pm 2,7$ нмоль/л $(3,4 \pm$ 0,21 мкг/100 мл).

Перспективи подальших досліджень будуть спрямовані на вивчення міграції біогенних мікроелементів, визначення їх вмісту в організмі тварин, які $\epsilon$ найбільш оптимальними біологічними індикаторами мінерального дисбалансу біогеоценозів. Порушення в організмі тварин вітамінно-мінерального гомеостазу, особливо у зимово-стійловий період, вимагає подальшого вивчення патогенезу одночасного розвитку зобу, проведення цілеспрямованих лікувальнопрофілактичних заходів - насамперед згодовування тваринам йодовмісних препаратів пролонгованої дії та комплексних мінеральних препаратів.

\section{Бібліографічні посилання}

Slavov, V.P., Romanchuk, L.D., Diduh, M.I. (1998). Efektyvnist' vykorystannja mineral'nyh dobavok $\mathrm{v}$ racionah dijnyh koriv $\mathrm{v}$ zoni radioaktyvnogo zabrudnennja Polissja Ukrai'ny. Nauka-Chornobyl'97: zb. tez nauk.-prakt., konf., 11-12 ljut. K. 89 (in Ukrainian).

Romanchuk, L.D. (1996). Radioekologichna ocinka racioniv $\mathrm{z}$ riznym rivnem mikroelementiv jak zasobu znyzhennja ceziju-137 v organizm zhujnyh: avtoref. dys. na zdobuttja nauk stupenja kand. s.-g. nauk. Zhytomyr, 18 (in Ukrainian).

Ligomina, I.P., Furman, S.V. (2008). Analiz ekologichnyh umov Polissja Ukrai'ny za vmistom shtuchnyh radionuklidiv ta vplyv i'h na organizm tvaryn. Nauk. visn. LNUVMET imeni S.Z. Gzhyc'kogo. 10, 4 (39), 150-154 (in Ukrainian).

Ligomina, I.P., Fasolja, V.P., Furman, S.V. (2013). Stan pryrodnoi' rezystentnosti i krovotvorennja ta metody i'h korekcii' u velykoi' rogatoi' hudoby v umovah tehnogennogo navantazhennja na dovkillja. Visn. Zhytomyr. nac. agroekol. un-tu. 2 (38), 1, 93-97 (in Ukrainian).

Sudakov, M.O., Bereza, V.I., Pogurs'kyj, I.G. [ta in.] (1991). Mikroelementozy sil's'kogospodars'kyh tvaryn; za red. M.O.Sudakova. 2-e vyd. K.: Urozhaj. 144 (in Ukrainian).

Romanjuk, V.L., Mandygra, M.S., Symyrenko, L.L. (1998). Funkcyonal'nyj stan shhytovydnoi' zalozy u teljat $\mathrm{Z}$ urodzhenym zobom $\mathrm{z}$ radioaktyvno zabrudnenogo gospodarstv. Naukovyj visn. NAU. K. 11, 170-173 (in Ukrainian).

Sudakov, M., Bereza, V., Pacjuk, M. (2000). Diagnostyka i profilaktyka jodnoi nedostatnosti u sil's'kogospodars'kyh tvaryn u biogeohimichnyh zonah Ukrai'ny. Vet. medycyna Ukrai'ny. 1, 30-31 (in Ukrainian).

Levchenko, V., Romanjuk, V., Fasolja, V. (2001). Hvoroby shhytovydnoi' zalozy. Vet. medycyna Ukrai'ny. 6, 35-37 (in Ukrainian).

Стаття надійшла до редакиії 27.09.2016 